УДК 373.21:37.036

DOI: $\underline{10.35619 / \text { iiu.v1i13.341 }}$

Проценко Ірина

кандидат педагогічних наук, доцент, доцент кафедри педагогіки

Сумського державного педагогічного університету імені А.С.Макаренка,

м. Суми, Україна

ORCID: 0000-0003-1792-7200

e-mail:procenkoira83@ukr.net

\title{
АНАЛІЗ ПРОБЛЕМИ ФОРМУВАННЯ ПРОФЕСІЙНОЇ КОМПЕТЕНТНОСТІ ВЧИТЕЛЯ НОВОЇ УКРАЇНСЬКОЇ ШКОЛИ
}

Анотація. У статті визначено сутність основних дефініцій «компетенція» - можливість встановлення зв'язку між знаннями i ситуацією, «професійна компетентність» - характеризується рівнем професійної освіти, досвідом та індивідуальними здібностями людини, іiі мотивованими прагненнями до безперервної самоосвіти та самовдосконалення, творчим і відповідальним ставленням до справи. 3'ясовано, що зміни у термінології основних понять зумовлені змінами як у педагогічній практиці, так і в теорії педагогічних систем: поняття компетенції увійшло до суспільних наук у цілому, зокрема педагогіки, психології, в управління і у сферу праці та організацій; модернізації змісту професійної підготовки; швидка поява нових і старіння раніше набутих знань, які вписуються нині в практичний досвід декількох поколінь i посилюють переконання людей, що наступні покоління повинні навчатися впродовж всього життя; зміни практик та технологій в системі навчання відбуваються в результаті змін способів і механізмів управління освітніми системами і регулювання ними.

Визначено, що професійно значущі якості вчителів залежать від особистості та визначаються, насамперед здібностями і характером. Складні особливості здібностей як організаторських, так і управлінських, уточнюються в окремих професійних здібностях. Тому необхідно чітко окреслити та обгрунтувати основу класифікації. 3'ясовано, що професіоналізм виступає як необхідна умова прояву компетентності, компетентність є показником ступеня відповідності, адекватності професіоналізму i змісту компетенції посади. Вихідний показник професійної компетентності вчителя Нової української школи у сучасних умовах - це сфера відношень до людини, оскільки вчитель працює в системі «людина - людина». Виокремлено структурні компоненти професійної компетентності вчителя Нової української школи: особистісно-гуманітарна спрямованість, системне сприйняття освітньої 
реальності, уміння інтегрувати інший досвід, креативність як спосіб буття в професії, здатність до рефлексії.

Ключові слова: компетентність, професійна компетентність, Нова українська школа, вчитель Нової української школи, структурні компоненти професійної компетентності, компетенція.

Постановка проблеми. На сучасному етапі розвитку освіти продовжується впровадження основних компетентностей учителя, особливо професійних. Відповідно Концепції «Нова українська школа» сучасна освіта спрямована на підвищення рівня підготовки майбутніх конкурентоспроможних фахівців, потрібних на ринку праці (Концепція «Нова українська школа», 2016). Державною національною програмою «Освіта» визначено основні напрями вдосконалення національної системи навчання: духовне самовдосконалення, творча самореалізація, підвищення професіоналізму педагогічних кадрів тощо.

Аналіз останніх досліджень з проблеми. Проблему визначення рівня професійної компетентності в системі освіти, його співвідношення 3 рівнем професійної кваліфікації та вдосконалення професіоналізму досліджували вітчизняні та зарубіжні вчені в різні періоди функціонування системи освіти: В. І. Бондар, І. П. Жерносек, Л. М. Карамушка, Л. І. Даниленко, В. Ю. Кричевський, В. І. Маслов, Г. В. Федоров, О. М. Карпенко, Л. І. Денисович, М. Д. Бертадська, Г. В. Сльнікова.

Мета статті - теоретичне дослідження проблеми формування професійної компетентності вчителя Нової української школи (НУШ).

Виклад основного матеріалу дослідження. У науково-педагогічній літературі розгляд значення низки понять «компетентність», «компетентний», компетенція», «професійна компетентність», «управлінська компетентність», зумовлена загальною метою професійної педагогічної освіти, а саме: формування управлінської компетентності, культури, духовності, моральних якостей. Кожне з понять має відповідну структуру, концепти, зміст і специфічні характерні ознаки. «Компетентність - слово латинського походження (competens відповідний) означає: 1) обсяг повноважень управлінського органу, посадової особи, коло питань, з якого вони мають право приймати рішення. Зона повноважень тих чи інших органів або осіб встановлюється законами, іншими підзаконними нормативними актами, положеннями, інструкціями, статутами; 2) знання, досвід у тій чи іншій галузі» (Зязюн, 2008). Поняття «компетентний» (від лат. competens - належний, відповідальний) визначається як досвідчений, обізнаний у проблемі, професії, певному питанні; наділений правом, повноважний, повноправний здійснювати певні операції, приймати рішення (Срмак, 2005).

Зміст поняття «компетенція» (від лат. competentia - належність за правом) трактується як сукупність повноважень (прав і обов'язків), якими у певній галузі діяльності наділені установи, підприємства, організації або службові особи. На думку багатьох учених, бачиться вирішеним поняття, 


\section{Інноватика у вихованні. Випуск 13.Том 1. 2021.}

що «компетенція» відноситься до сфери умінь, а не лише знань. «Компетенція - це загальна здібність особистості, що базується на знаннях, досвіді, цінностях, нахилах i яка набувається завдяки навчанню. Компетенція не зводиться ні до знань, ні до вмінь. Бути компетентним - це означає бути вченим або освіченим» (Овчарук, 2004). Крім того, слід розрізняти основні концепти поняття компетенція і вміння. Уміння - це дії особистості (doing) в специфічній ситуації, це прояв компетенції або здібності (a capability), або можливості здійснювати дії в специфічній ситуації.

Компетенцію слід розглядати як можливість встановлення зв'язку між знаннями і ситуацією, або в ширшому значенні, як здатність знайти, виявити процедуру (знання і дію), яка підходить до розв'язання проблеми, ситуації, однак в будь-якому випадку не слід спрощувати поняття компетенції.

Поширення поняття «компетенція» в значенні «уміння» заслуговує на увагу вчених і практиків у зв’язку з тим, що зміни термінології часто призводять до глибоких змін як в педагогічній практиці, так і в теорії педагогічних систем. До найбільи суттєвих можна виділити такі (Сергійчук, 2008):

1) поняття компетенції увійшло до суспільних наук у цілому, зокрема, педагогіки, психології, в управління і в сферу праці та організацій; 2) реформування системи освіти викликає почуття незадоволеності й дискомфорту в аспекті модернізації змісту професійної підготовки (Вдовиченко, 2003); 3) швидка поява нових і старіння раніше набутих знань, які гармонізуються нині в практичний досвід декількох поколінь і посилюють переконання людей, що наступні покоління повинні навчатися впродовж всього життя; 4) зміни практик та технологій у системі навчання відбуваються в результаті повільних змін способів і механізмів управління освітніми системами і регулювання ними.

Компетенція не може бути визначена через конкретну суму знань i умінь, оскільки іiі прояв значною мірою залежить від обставин. Бути компетентним, означає вміти мобілізувати в такій ситуації отримані знання і досвід. При розгляді поняття «компетенція» зосереджується увага на конкретні ситуації, в яких вони проявляються.

Отже, компетенції не зводяться ні до знань, ні до умінь. Часто можна зустріти людей, які володіють великим об'ємом знань, але не можуть мобілізувати їх належним чином у потрібній ситуації, коли випадає можливість їх реалізувати.

Останнім часом в науковому обігу широко використовується термін «ключові компетенції», який розглядається як інструмент, що відкриває двері і доступ до оволодіння новими ситуаціями. «Ключова компетенція це визначена компетенція тому, що вона відповідає умовам реалізації, які $\epsilon$ певною мірою універсальними». У контексті професійної підготовки директорів закладів освіти легко зрозуміти, 3 якої причини віддають перевагу розвитку в суб'єктів компетенцій широкого спектра, що можуть 


\section{Інноватика у вихованні. Випуск 13.Том 1. 2021.}

проявитися в найрізноманітніших ситуаціях та умовах. Набуття компетенції грунтується на досвіді та діяльності суб'єктів. Саме цю точку зору поділяють багато європейських експертів з освіти (Темерівська, 2004).

На думку О. Полякової, категорія «професійна компетентність» визначається, як правило, рівнем професійної освіти, досвідом та індивідуальними здібностями людини, іiі мотивованими прагненнями до безперервної самоосвіти та самовдосконалення, творчим і відповідальним ставленням до справи. Елементи всіх цих якостей повинні бути наявними не тільки в структурі та змісті загальної освіти, а й в структурі грамотності (Полякова, 1999).

У сучасних дослідженнях фахову компетентність обгрунтовують як у складі професійної, так і проводячи між ними аналогію. Досліджуючи професійну компетентність, Н. Тарасевич обов'язковою іiі складовою визначає фахову, тлумачучи їі як складову підготовленості особистості фахівця, що проявляється в його здатності та готовності до здійснення конкретного виду професійної діяльності (Тарасевич, 2005).

Більшість дослідників використовують поняття «професійна компетентність» як характеристику професійної діяльності особистості. I. О. Пальшкова доводить, що професійна компетентність осіб, які працюють у системі «людина - людина», визначається базовими знаннями та вміннями, ціннісними орієнтирами, мотивами його діяльності, розумінням ним себе у світі і світу навколо себе, стилем взаємодії 3 людьми, загальною культурою, здатністю до розвитку творчого потенціалу (Коберник, 2002).

Здійснюючи критичний аналіз класифікації професійно значущих якостей учителів, на нашу думку, дослідникам слід було врахувати, що якості особистості визначаються, насамперед, здібностями і характером, а такі здібності, як організаторські та управлінські, конкретизуються в окремих професійних здібностях, i необхідно чітко окреслити та обгрунтувати підходи до їх класифікації.

Професійна компетентність у будь-якій сфері для особистості $\epsilon$ необхідним компонентом залучення людини до культури. Професійний досвід керівника знаходить прояв у його діяльності, пов'язаній 3 реалізацією посадових функцій i розв'язанням професійних задач та ситуацій. Щодо професійної діяльності вчителя, то тут питання компетентності безпосередньо пов'язане 3 професіоналізмом. Професіоналізм виступає як необхідна умова прояву компетентності, компетентність $є$ показником ступеня відповідності, адекватності професіоналізму і змісту компетенції посади.

Вихідний показник професійної компетентності вчителя Нової української школи у сучасних умовах - це сфера ставлень до людини, оскільки вчитель працює в системі «людина - людина». Варто звернути увагу на структурні компоненти професійної компетентності вчителя Нової української школи: особистісно-гуманітарна спрямованість, 


\section{Інноватика у вихованні. Випуск 13.Том 1. 2021.}

системне сприйняття освітньої реальності, уміння інтегрувати інший досвід, креативність як спосіб буття в професії, здатність до рефлексії.

I. Онищенко, здійснюючи аналогію між професійною та фаховою компетентностями вчителя Нової української школи, досить вдало, на нашу думку, обгрунтовує основні компоненти цих компетентностей. Зокрема авторка виокремлює: мотиваційний компонент (забезпечує позитивну мотивацію учителя початкової школи до прояву і розвитку професійно-педагогічної компетентності, що виражається в інтересі до педагогічної діяльності, бажанні працювати вчителем початкової школи, потребі у самоосвіті, саморозвитку); змістовий компонент (охоплює такі елементи компетентності, як володіння науковими професійнопедагогічними знаннями (психолого-педагогічними, методичними, спеціальними, загальноосвітніми, управлінськими, інформаційнотехнологічними), здатність педагогічно мислити на основі системи знань та досвіду пізнавальної діяльності); операційно-діяльнісний компонент (уміння практично вирішувати педагогічні завдання, наявність фахового досвіду, творчих здібностей, володіння педагогічними технологіями та педагогічним менеджментом, фахове мислення); особистісний компонент (любов до дітей, доброта, альтруїзм, емпатійність, толерантність, моральна чистота, комунікабельність, конгруентність, активність, самостійність, ініціативність, креативність, гнучкість мислення); рефлексивний компонент професійної компетентності (реалізується у рефлексивних уміннях особистості, що дозволяють ефективно та адекватно здійснювати рефлексивні процеси, реалізовувати рефлексивні здібності, забезпечувати процеси самопізнання, саморозвитку й самовдосконалення (Сергійчук, 2008).

Висновки і перспективи подальших розвідок. На нашу думку, ці компоненти в повній мірі розкривають структуру фахової компетентності вчителя НУШ та сприяють чіткому виокремленню шляхів їі розвитку. Формування фахової компетентності як інтегрального результату педагогічної освіти вчителя здійснюється в умовах врахування мотиваційної сфери його особистості; самоосвіти, виховання та самовиховання; індивідуалізації й диференціації навчання, оптимізації змісту навчального процесу; професійно-орієнтованого характеру процесу навчання; міжпредметності зв'язків; стимулювання їх потреб у розширенні кругозору тощо. Це загальновизнані шляхи формування компетнентності, що стають підгрунтям для пошуку нових інноваційних умов для досягнення поставленої мети освіти.

Таким чином, аналіз змісту базових понять дослідження «компетентність», «компетентний», «компетенції» дозволив 3'ясувати їх сумісні характеристики та взаємозв'язок між ними. Наведені поняття розкриваються авторами з позицій різних наукових підходів до визначення їх змісту, а саме функціонального та інформаційного. Суть репрезентована через коло функціональних повноважень та інформацію, що дозволяє особі 


\section{Інноватика у вихованні. Випуск 13.Том 1. 2021.}

або органу управління приймати обгрунтовані та виважені управлінські рішення.

\section{СПИСОК ВИКОРИСТАНИХ ДЖЕРЕЛ}

Концепиія «Нова Украӥнська школа» (2015). URL: novashkola@mon.gov.ua. [Дата звернення 06.03.21].

Зязюн, І. (2008). Філософія педагогічної дії: монографія. Черкаси. $608 \mathrm{c}$.

Закон України «Про вищу освіту» (2014). URL: zakon.rada.gov.ua>laws/1556- 18. [Дата звернення 06.03.21].

Професійна педагогічна освіта: компетентнісний підхід: монографія. Житомир. 412 с.

Полякова, О. (1999). Формування творчої активності майбутніх учителів у процесі розв'язання педагогічних задач: Кандидат педагогічних наук. Харків. 188 с.

Тарасевич, Н. (2005). Стратегія поведінки вчителя у складних педагогічних ситуаціях: Спецкурс. Тексти лекцій. Полтава: ІОЦПДПУ. 119 c.

Темерівська, Т. (2004). Формування пізнавальної активності студентів медичного коледжу в процесі вивчення природничо-наукових дисииплін: Кандидат педагогічних наук. Тернопіль, 197 с.

Срмак, Н. (2005). Педагогічна практика як чинник професійного формування вчителя загальноосвітньої школи. Наук. часопис Нач. пед. унту ім. М.П. Драгоманова. Сер. 16. Творча особистість учителя: проблеми теорії і практики: Зб. наук. пр. К.. Вип. 3 (13). 290 с.

Сергійчук, О. (2008). Професійна компетентність майбутнього вчителя. Підготовка студентів до майбутньої професійної діяльності : науково-теорет. зб. Пер.-Хм. : СКД, Вип. 1. 254 с.

Вдовиченко, Р. (2003) Між професійною підготовкою та компетентністю. Управління освітою (Шкільний світ). № 15-16. СС. 2-3.

Коберник, О. (2002). Розробка творчих проектів на уроках технічної праці. Трудова підготовка в закладах освіти. № 1. СС. 41-45.

Овчарук, О. (2004). Розвиток компетентнісного підходу : стратегічні орієнтири міжнародної спільноти. Компетентнісний підхід у сучасній освіті: світовий досвід та українські перспективи: бібліотека з освітньої політики. Київ. «К.І.С». СС. 6-15.

\section{REFERENCES}

Kontseptsiia "Nova Ukrainska shkola"(2015). [The concept of the "New Ukrainian School"] URL: novashkola@mon.gov.ua. [Data zvernennia 06.03.21] [in Ukrainian].

Ziaziun, I. (2008). Filosofiia pedahohichnoi dii: monohrafiia. [Philosophy of pedagogical action: monograph]. Cherkasy. 608 s. [in Ukrainian]. 


\section{Інноватика у вихованні. Випуск 13.Том 1. 2021.}

Zakon Ukrainy "Pro vyshchu osvitu" [Law of Ukraine "On higher education"] (2014). URL: zakon.rada.gov.ua>laws/1556- 18. [Data zvernennia 06.03.21] [in Ukrainian].

Profesiina pedahohichna osvita: kompetentnisnyi pidkhid: monohrafiia. [Professional pedagogical education: competence approach: monograph]. Zhytomyr. 412 s. [in Ukrainian].

Poliakova, O. (1999). Formuvannia tvorchoi aktyvnosti maibutnikh uchyteliv u protsesi rozviazannia pedahohichnykh zadach: [Formation of creative activity of future teachers in the process of solving pedagogical problems: Kandydat pedahohichnykh nauk. Kh. 188 s. [in Ukrainian].

Tarasevych, N. (2005). Stratehiia povedinky vchytelia u skladnykh pedahohichnykh sytuatsiiakh: Spetskurs. Teksty lektsii. [Strategy of teacher behavior in difficult pedagogical situations: Special course. Lecture texts]. Poltava: IOTsPDPU. 119 s. [in Ukrainian].

Temerivska, T. (2004). Formuvannia piznavalnoi aktyvnosti studentiv medychnoho koledzhu $v$ protsesi vyvchennia pryrodnycho-naukovykh dystsyplin: Kandydat pedahohichnykh nauk. [Formation of cognitive activity of students of medical college in the course of studying of natural sciences]: Kandydat pedahohichnykh nauk Ternopil, 197 s. [in Ukrainian].

Yermak, N. (2005). Pedahohichna praktyka yak chynnyk profesiinoho formuvannia vchytelia zahalnoosvitnoi shkoly. [Pedagogical practice as a factor in the professional formation of a secondary school teacher] Nauk. chasopys Nats. ped. un-tu im. M.P. Drahomanova. Ser. 16. Tvorcha osobystist uchytelia: problemy teorii i praktyky: Zb. nauk. pr. Kyiv. Vyp. 3 (13). 290 s. [in Ukrainian].

Serhiichuk, O. (2008). Profesiina kompetentnist maibutnoho vchytelia. Pidhotovka studentiv do maibutnoi profesiinoi diialnosti: naukovo-teoret. $\mathrm{zb}$. [Professional competence of a future teacher. Preparing students for future professional activities: scientific theory] Per.-Khm. : SKD, Vyp. 1. 254 s. [in Ukrainian].

Vdovychenko, R. (2003). Mizh profesiinoiu pidhotovkoiu ta kompetentnistiu. [Between professional training and competence]. Upravlinnia osvitoiu (Shkilnyi svit). No 15-16. SS. 2-3. [in Ukrainian].

Kobernyk, O. (2002) Rozrobka tvorchykh proektiv na urokakh tekhnichnoi pratsi. [Development of creative projects in lessons of technical work]. Trudova pidhotovka $v$ zakladakh osvity. No 1. SS. 41-45. [in Ukrainian].

Ovcharuk, O. (2004). Rozvytok kompetentnisnoho pidkhodu : stratehichni oriientyry mizhnarodnoi spilnoty. [Development of the competence approach: strategic guidelines of the international community] Kompetentnisnyi pidkhid $u$ suchasnii osviti: svitovyi dosvid ta ukrainski perspektyvy: biblioteka z osvitnoi polityky. K. "K.I.S”. S. 6-15. [in Ukrainian]. 


\title{
ANALYSIS OF THE PROBLEM OF FORMATION OF PROFESSIONAL COMPETENCE FOR TEACHERS OF THE NEW UKRAINIAN SCHOOL
}

\author{
Iryna Protsenko \\ Candidate of Pedagogical Sciences, Associate Professor, \\ Associate Professor at the Departnent of Pedagogy \\ A.S. Makarenko Sumy State Pedagogical University, \\ Sumy, Ukraine \\ ORCID: 0000-0003-1792-7200 \\ e-mail:procenkoira83@ukr.net
}

\begin{abstract}
The article defines the essence of the main definitions of "competence" - the ability to establish a link between knowledge and the situation, "professional competence" - is characterized by the level of professional education, experience and individual abilities, motivated aspirations for continuous self-education and selfimprovement, creative and responsible attitude to affairs. It was found that changes in the terminology of basic concepts are due to changes in both pedagogical practice and in the theory of pedagogical systems: the concept of competence has entered the social sciences in general, in particular, pedagogy, psychology, management and work and organizations; modernization of the content of professional training; the rapid emergence of new and aging previously acquired knowledge, which now fit into the practical experience of several generations and strengthen people's belief that future generations should learn throughout life; changes in practice and technology in the education system occur as a result of slow changes in the methods and mechanisms of management of educational systems and their regulation.

It is determined that the professionally significant qualities of teachers depend on the individual and are determined primarily by abilities and character, and complex features of ability, such as organizational and managerial, are specified in individual professional abilities, and it is necessary to clearly define and justify the classification. It was found that professionalism acts as a necessary condition for the manifestation of competence, competence is an indicator of the degree of compliance, adequacy of professionalism and the content of the competence of the position. The initial indicator of the professional competence of a teacher of the New Ukrainian School in the current situation is the sphere of relations to a person, as the teacher works in the system "person-person". The structural components of the professional competence of the teacher of the New Ukrainian school are singled out: personal-humanitarian orientation, systematic perception of educational reality, ability to integrate other experience, creativity as a way of being in the profession, ability to reflect.
\end{abstract}

Keywords: competence, professional competence, New Ukrainian school, teacher of the New Ukrainian school, structural components of professional competence, competence.

Стаття надійшла до редакиії 23.03.2021p. 